\title{
Sciendo
}

\section{The Effect of External Knowledge Sources on Organizational Innovation in Small and Medium Enterprises in Germany}

\section{Shoaib Abdul Basit}

Faculty of Economics and Business Administration, Chemnitz University of Technology, Germany

\section{Abstract}

Background: Firms increasingly depend on external actors for the process of generating innovation. Interaction with these actors might occur through an official collaboration agreement or via external actors as the source of information. Objectives: Although open innovation has received more attention, still less is known about its effect on organizational innovation. To fill this gap, this study investigates the impact of various external knowledge sources on the willingness of small and mediumsized enterprises to introduce organizational innovation. Methods/Approach: To achieve the proposed objective, the German Community Innovation Survey conducted in 2017 is used for the econometric analysis. Results: Different external sources of knowledge are relevant for the introduction of organizational innovation in small firms (customers in the private sector, competitors, conferences, and crowdsourcing) compared to medium-sized firms (customers in the private sector and industry associations). Conclusions: External knowledge sources are more important for small firms compared to medium firms, and those small firms are more likely to use various sets of external knowledge.

Keywords: organizational innovation; workplace; external knowledge sources; small and medium-sized firms

JEL classification: $\mathrm{O} 31, \mathrm{O} 36$

Paper type: Research article

Received: Jan 132020

Accepted: Jun 252020

Citation: Abdul Basit, S. (2021), "The Effect of External Knowledge Sources on Organizational Innovation in Small and Medium Enterprises in Germany", Business Systems Research, Vol. 12, No. 1, pp. 60-79.

DOI: https://doi.org/10.2478/bsrj-2021-0005 


\section{Introduction}

Innovation is considered an important factor for firms' longevity in the marketplace. In literature, many scholars confirm that innovation is the key element for growth (Schumpeter, 1934; Volberda et al., 2014). The broad definition of innovation is described as the implementation of significantly improved or new product and service as well as process, and the introduction of a new marketing method or a new organizational system at the firms' workplace or the adoption of new organizational procedures in occupational practices (OECD, 2005).

Chesbrough presents the concept of open innovation and highlights the significance of external sources of information for the innovation process and further posits that internal R\&D is no longer any more strategic assets for the firms, once it was (Chesbrough, 2003). Open Innovation provides valuable knowledge for better innovation performance and its widely acknowledged as a key factor for innovation management practices (Chesbrough et al., 2014).

The role of external sources of knowledge as an important factor of innovation has received significant attention in the literature. Numerous empirical studies claim that increasing openness towards external knowledge enhances firms' innovation performance (Van de Vrande et al., 2009; Leiponen and Helfat, 201 1; Gómez, et al., 2016). Previous studies identify the variety of useful external sources of knowledge and their effect on innovation. For instance, knowledge sources are considered as the information transfer channels through informal networks such as competitors, suppliers, universities and customers (Gassmann and Enkel, 2004).

Despite a growing literature on the effect of various sources of external knowledge on different types of innovation, prior studies mostly focus on a general effect of external knowledge from the customers without delineating into the public and private sector. It is also notable that sourced knowledge from competitors, suppliers, and public research institutes is limited to product innovation (Tsai, 2009; Spithoven et al., 2013; Köhler et al., 2012). Also, most scholars focused on external sources impact in general on technological innovation i.e., radical or incremental innovation (Wang and $\mathrm{XU}, 2018$; Zouaghi et al., 2018) and technology innovation performance (Kang and Kang, 2009) and new product development (Santoro et al., 2018a; IglesiasSánchez et al., 2019) and product and process innovation (Dotzel and Faggian, 2019; Criscuolo et al., 2018).

Some previous studies argue that various types of external sources of knowledge differ significantly for firms' innovation performance (Kang and Kang, 2009; Köhler et al. 2012). In addition, Knoben and Oerlemans (2010) reveal that the effect of various external sources of knowledge on innovation output differs significantly and further suggest that it is beneficial to differentiate the various types of external knowledge sources as well as the diverse level of novelty to the innovation outcomes. Therefore, to develop a suitable strategy for the type of knowledge search, it is strongly needed to understand the effect of the various external knowledge search on firm innovation activities.

Also, West and Bogers (2014) provide the literature review of research on open innovation and suggest that further research is required on individuals as a source of innovation. However, the scholars examine the impact of sources of knowledge on innovation output but without considering the various types of external knowledge sources for innovation activities in small and medium firms. Although scholars acknowledge that SMEs play an important role in innovation (Chesbrough et al., 2006), however, researchers have scarcely explored how small and medium enterprises use 
various sources of ideas and knowledge for innovation (Brunswicker and Vanhaverbeke, 2015). Previous research on open innovation mostly focused on large firms ( Hinteregger et al., 2019; Bogers et al., 2017; van de Vrande et al., 2009), although studies claim that SMEs play a vital role in economic growth (Muller et al., 2015; Gassmann, et al., 2010). Further, some scholars repeatedly stress the importance of SMEs and suggest that there is a need to explore in-depth open innovation in SMEs (Wynarczyk, 2013; Spithoven et al., 2013; van de Vrande et al., 2009) and also open innovation in SMEs receive less attention from scholars (Hossain, 2013). Consequently, the present study considers small and medium-sized firms to offer a deeper understanding of how SMEs involve in the sources of open innovation.

Therefore, the present paper recognizes the key research gap in the existing literature on how the relationship with external partners can bring the information needed to adopt an extensive range of internal organizational innovation practices, which might enhance firm performance at the workplace. As observed in the literature, scholars emphasis on the impact of external knowledge sources from customers in general (without delineating customers from the public and private sector), competitors, suppliers, public research institute and its impact is limited to product innovation (Tsai, 2009; Fitjar and Rodríguez-Pose, 2013; Köhler et al., 2012) and on internal and external R\&D activities (Pejić Bach et al., 2015). Research conducted on various external sources of knowledge and their effect on organizational innovation is scarce. Hence, the present study aims to shed more light on this particular topic by addressing the following research question: Do various external sources of knowledge from conferences, customer private, customer public, industry associations, competitors and from crowdsourcing have an effect on organizational innovation in small and medium enterprises? This study contributes to the current literature by considering the specific external knowledge sources (i.e conferences, industry associations, customers from the public and private sector, and crowdsourcing: ideas from the general public) and its impact on organizational innovation in terms of decision making and the adoption of new methods of work organizing responsibilities at the working place in SMEs. The present research is mainly triggered by West and Bogers (2014), who reviews the literature on open innovation and suggest examining the effects of individual external knowledge sources on innovation. However, the scholars mainly examine the combined effect of the sources of external knowledge on innovation outcomes but without considering the various types as an individual source of external knowledge for innovation activities in small and medium firms. The identification and suitability of the various sorts of external partners available to share their information and knowledge freely may decrease costs that are linked with formal forms of collaboration to enhance organizational innovation in the firm's workplace. Additionally, this study advances research by considering the different modes of external knowledge sources impact on organizational innovation in small and medium-sized enterprises separately, as the researchers have scarcely explored how small and medium enterprises use various sources of ideas and knowledge to enhance innovation performance (Brunswicker and Vanhaverbeke, 2015). Thus, recognizing the certain type of external knowledge source could be beneficial for the firms to know whether the specific information sources affect the introduction of organizational innovation in small and medium-sized firms according to their needs.

The rest of the paper is organised as follows. First, the theoretical background of the study and hypothesis development are presented. Then, the data source and statistical methods are described. Third, the details of descriptive statistics and the 
empirical findings are discussed. Finally, the paper provides the discussion, conclusions, and policy implications.

\section{Theoretical background}

\section{Organizational innovation}

Literature shows that organisational knowledge plays a significant role in competitive benefits in the market, as it helps the organization to create identical and valuable ways to compete (Hall, 1992; Reed and DeFillippi, 1990). Similarly, Tsoukas (1996) highlight that those firms which contain the organizational knowledge about how to utilize the resources can attain a high degree of efficiency and effectiveness in the organization. In addition, organizational changes are linked with better performance (Greenan and Mairesse, 2003), and the introduction of new methods, management tools, as well as practices that enable organizational changes and eventually advance the organizational competitiveness (Damanpour, 2014).

Mostly prior research acknowledged the importance of traditional innovation types (namely, product and process innovation) and their economic impact (Hervas-Oliver et al., 2015; Brettel and Cleven, 2011). Likewise, Keupp et al. (2012) conduct a systematic literature review on strategic management of innovation view and find that out of 342 studies, 246 studies include the product and process innovation while only 23 studies consider the non-technological innovations (i.e. marketing and organizational innovation) in their analyses. Focusing mostly on technological innovation (i.e. product and process innovation) signifies a research gap and in the future, it would not be sufficient to ensure the success of innovation (Eurostat, 2016). In this aspect, many scholars argue that technological innovations need to be downsized and more attention should be given to the importance of nontechnological innovation (Volberda et al., 2014; Damanpour, 2014).

In the acknowledgement of organizational innovation, previous studies shed lights on the importance of organizational innovation and support that there is a positive effect of organizational innovation on performance outcomes (Anzola-Román et al., 2018; Chen et al., 2019). In addition, others stress this link even more and state that organizational innovation could support long term competitive benefit to the firms, as it is a resource that is firm-specific, unique, valuable and difficult to replicate (Damanpour, 2014; Mol and Birkinshaw, 2009).

Moreover, organizational innovations are frequently intended to improve workplace satisfaction, enhance the exchange of valuable knowledge and boost a firm's capability to learn from the environment and use new knowledge and reduces administrative and transaction costs (OECD, 2005). As the concept of innovation has changed from a technological innovation into a broader viewpoint with the OECD inclusion of non-technological innovation and particularly organization innovation. Hence, this change needs a comprehensive analysis of how external knowledge sources influence organizational innovation.

\section{Knowledge sources and organizational innovation}

Open innovation is acknowledged as an important ingredient for innovation management (Gassmann and Enkel, 2004). The idea of blending sources of external knowledge (instead of depending on internal sources only) for the innovation process has been emphasized frequently in the previous studies on innovation. Through different approaches, previous studies highlight the importance of taking benefit from 
external sources of knowledge to improve organizational innovation (Ferraris et al., 2017; Cohen, and Levinthal, 1990).

Many scholars highlight the variety of useful external sources of knowledge such as customers, competitors, suppliers, universities, consultants, professional and industrial associations (Gassmann and Enkel 2004; Chesbrough, 2003). Innovation studies show that knowledge source from various partners is considered as a significant factor for innovation success (Mol and Birkinshaw, 2014; Gellynck and Vermeire, 2009). Further, different types of external knowledge source i.e. suppliers, clients, and universities are linked with a series of advantages. These external actors give access to the external source of knowledge (Teece, 1986) and especially this is relevant in the case of knowledge transfer which is tacit and not easily modifiable (Hippel, 1988).

In this sense, firms do not operate in the market alone but also get benefit from the external environment such as external sources of knowledge. Hence, in the purpose of the present study, it is essential to know the effect of external sources of knowledge on organizational innovation. This study considers six types of external knowledge sources called as: i) customers from public sector ii) customers from private sector iii) conferences iv) industry associations v) competitors vi) crowdsourcing i.e. ideas from the general public. These six sources are selected for two main reasons. First, the role of this external knowledge on the innovation process is well established in the existing literature (Tidd et al., 2005). Secondly, these sources are certain organizations that show the source of knowledge that they include.

\section{Hypothesis development}

Knowledge sources from customers are considered an important factor for organizational innovation (Tether and Tajar, 2008b). The new ways of organizing firms' customers' interaction can enhance firms' organizational innovation performance. As customers know their needs and expectations, so they provide valuable knowledge to the firms (Santoro et al., 2018b; Tether, 2002) and therefore it encourages the firms to adopt the innovation practices at the firm workplace (Guler et al., 2002). Firms can get benefit from the external knowledge sources for innovation capabilities that some firms do not possess and such external knowledge sources might grant access to innovation (West and Bogers, 2014). Previous studies argue that information sources from the customers, suppliers, competitors, and consultants make it possible for the firms to bring new ideas for the innovation through combining these external information sources with their internal existing knowledge (Tether and Tajar 2008a; Lefebvre et al., 2015).

Moreover, Birkinshaw et al. (2008) argue that external partners (such as suppliers as well as clients, form a common and cooperative group of partners) share the management knowledge which encourages the adoption of the firm's organizational innovation. Further, Mol and Birkinshaw (2009) point out that the uses of greater breadth of external knowledge search by the firms lead to the greater introduction of new management practices. Feedbacks from the customers are very important, as the customers provide first-hand user experiences and inform their sensitivity to the market trend and customers also evaluate the firm's new product concept (Chang and Taylor, 2016). Thus, this present study contends that firms may adopt new organizational innovation at the firms' workplace when ideas are offered by customers from the public and private sector and crowdsourcing (i.e. ideas from the general public). This leads to the following hypothesis: 
- H1. Knowledge source through the customers in the private sector positively influences firms' propensity to undertake organizational innovation at the firms' workplace.

- H2. Knowledge source through the customers in the public sector positively influences firms' propensity to undertake organizational innovation at the firms' workplace.

- H3. Knowledge source from crowdsourcing such as ideas from the general public positively influences firms' propensity to undertake organizational innovation at the firms' workplace.

Information source from competitors is significant to firms as rivals mostly require similar needs for their innovation process (Lhuillery and Pfister, 2009). Also, competing firms face similar technological issues, so market collaboration with competitors and customers support firms to obtain new technological knowledge as well as to practice and access other information sources (Gnyawali and Park, 2011). Further, cooperation with competitors also provides opportunities to seek a successful organizational structure from the rivals (Pippel, 2014). It is also possible when all face the same issues in the market which might be outside of the competition area, for instance, the creation of regulatory structure in the operating market (Tether, 2002). Further, market partners provide operational knowledge which is related to the focal firms for improvement of the organization process (Al-Laham et al., 2010). Therefore, in this way, it might encourage the development of organizational structure at the firms' workplace. Based on the presented literature, the following hypothesis is formulated:

- H4. Knowledge source from the competitors positively influences firms' propensity to undertake organizational innovation at the firms' workplace.

Some scholars argue that information sources from the specialist knowledge providers (such as consultants, trade associations, private research organizations, and universities) are more likely to be used by firms that tend to complement their internal innovation activities (Lefebvre et al., 2015; Tether and Tajar, 2008a). Further, external knowledge sources from conferences and trade fairs are presumed to serve as an instrument where firms can make connections with various potential knowledge suppliers and then firms can obtain knowledge from these sources (Sofka and Grimpe, 2010). Additionally, knowledge sources from scientific and industry publications, trade fairs and conferences are easily accessible and almost no barriers exist to access knowledge from these sources. Moreover, Sofka and Grimpe (2010) argue that externally available information sources from science-driven search strategy such as knowledge source from public research centres and universities and supply-driven search strategy including conferences, trade fairs, and suppliers enhance innovation performance. Based on the aforementioned discussion, the following hypothesis is proposed:

- H5. Knowledge source from conferences positively influences firms' propensity to undertake organizational innovation at the firms' workplace.

Firms that are associated with business groups take advantage of intragroup network resources which are different from those sources acquired from its externally inter-firm networks (Yiu et al., 2005). Additionally, some studies argue that business groups offer group-level resources different from those provided by the external networks and further business group-level resources are very important for innovation, especially when the market infrastructures are in a developing stage (Choi et al., 201 1; Chang et al., 2006).

The share of tacit management knowledge happens when firms operate in a similar market and firms possess similar competencies, resources, and skills, thus such similarity 
results in collaboration with others for the implementation of new knowledge (Mowery et al., 1996). Moreover, Turulja and Bajgorić (2018) claim that for organizational learning shared values and openness play a positively significant role in the knowledge management competencies of the firms. Hence, the present study argues that industry associations should enhance firms' organizational innovation at the firms' workplace through knowledge transfer and industry complementarity. This leads to the following hypothesis:

- H6. Knowledge source from the industry associations positively influences firms' propensity to undertake organizational innovation at the firms' workplace.

In the next section, we discuss the dataset, characteristics of perspective estimation variables, and the statistical method used for the analysis.

\section{Methodology}

\section{Data}

The present study examines the Mannheim Innovation Panel (MIP) database. The MIP database is financed by the German Federal Ministry of Education and Research and MIP is the German part of the Community Innovation Survey. Since 1993, the Center for European Economic Research (ZEW) has been conducting the annual survey (in Germany) on innovation activities with the firms having at least 5 employees. The MIP data is collected by sending the questionnaires via email. The survey methodology is based on the recommendations of Eurostat and OECD Oslo Manual on innovation statistics. In the survey, the managers are asked about their firms' process for generating innovation. Therefore, the MIP database provides an extensive variety of general information on innovation activities i.e. firm size, sector of activity, geographical markets, product, process, marketing and organizational innovations, external knowledge sources for innovation etc.

This study employs the data from MIP by using the survey wave conducted in the year 2017 that is referred to as Community Innovation Survey (CIS 2017). CIS (2017) covers the years from 2014 - 2016 and includes information about the sector of business group activities, external information sources, geographical market, firm size, and innovation activities. This sample considers the German manufacturing and service firms and provides information regarding the introduction of new products, services, and innovation process (such as product, process, marketing, and organizational) within firms.

\section{Research instrument}

The first part contains the information on organizational innovation (the dependent variable) measured as the introduction of new methods of organizing work responsibilities and decision making at the firm workplace. It is a binary variable that corresponds to the measurement of organisational innovation at the workplace (see Abdul Basit et al., 2018). This organizational innovation measurement is proposed by the OECD (2005) and it is widely used in the literature. The third part measures the innovations in logistics as a digital innovation supply chain management (Diginnospmana) for robustness check. The dummy variable "Diginnospmana" takes the value of " 1 " if the firm introduced innovations in logistics as a digital supply chain management and "O" otherwise. 
Table 1

Dependent variables

\begin{tabular}{|c|c|c|c|}
\hline Variable code & Variable name & Type & Description \\
\hline $\begin{array}{l}\text { Organizational } \\
\text { inno }\end{array}$ & $\begin{array}{l}\text { Organizational } \\
\text { innovation }\end{array}$ & Dummy & $\begin{array}{l}1 \text { if the firm introduced new methods of } \\
\text { organizational innovation (i.e new methods of } \\
\text { organizing work responsibilities and decision } \\
\text { making) activities in the period of } 2014-2016 \text { and } 0 \\
\text { otherwise }\end{array}$ \\
\hline Diginnospmana & $\begin{array}{l}\text { Digital supply } \\
\text { chain } \\
\text { management }\end{array}$ & Dummy & $\begin{array}{l}1 \text { if firm introduced innovations in logistics as a } \\
\text { digital supply chain management (i.e. including } \\
\text { planning, organization, management, paperless, } \\
\text { transparent supply chain transactions) from } 2014 \\
\text { to } 2016 \text { and } 0 \text { otherwise }\end{array}$ \\
\hline
\end{tabular}

Source: Author work

The second part measures the source of information for new ideas for innovation projects. These information sources include six distinctive external knowledge sources, namely knowledge sources from the customers in the public and private sector, conferences, competitors, industry associations and crowdsourcing to measure the independent variables. Community Innovation Survey (CIS) 2017 asks the respondents about the degree of importance of various external knowledge sources usage for innovation activities. CIS 2017 measures the importance of these information sources in firms' innovative activities as high, medium, low and not used. Thus, for the aim of this paper, the variables are re-scaled as binary: "0" not perceived by the firm as a type of information source; "1" perceived by the firm as a type of information source. These knowledge sources are measured following previous studies (Tether and Tajar, 2008b, Tsai, 2009).

Table 2

Independent variables - Knowledge sources for innovation

\begin{tabular}{|c|c|c|c|}
\hline Variable code & Variable name & Type & Description \\
\hline Customer_private & $\begin{array}{l}\text { Customers from } \\
\text { the private sector } \\
\text { as the source of } \\
\text { knowledge }\end{array}$ & Dummy & $\begin{array}{l}1 \text { if the firm receives new ideas from the } \\
\text { customers from a private sector between } \\
2014 \text { and } 2016 \text { and } 0 \text { otherwise }\end{array}$ \\
\hline Customer_public & $\begin{array}{l}\text { Customers from } \\
\text { the public sector } \\
\text { as the source of } \\
\text { knowledge }\end{array}$ & Dummy & $\begin{array}{l}1 \text { if the firm receives new ideas from } \\
\text { customers from the public sector between } \\
2014 \text { and } 2016 \text { and } 0 \text { otherwise }\end{array}$ \\
\hline Competitors & $\begin{array}{l}\text { Competitors as the } \\
\text { source of } \\
\text { knowledge }\end{array}$ & Dummy & $\begin{array}{l}1 \text { if the firm receives new ideas from } \\
\text { competitors between } 2014 \text { and } 2016 \text { and } 0 \\
\text { otherwise }\end{array}$ \\
\hline Conferences & $\begin{array}{l}\text { Conferences as } \\
\text { the source of } \\
\text { knowledge }\end{array}$ & Dummy & $\begin{array}{l}1 \text { if the firm receives new ideas from } \\
\text { conferences, trade fairs between } 2014 \text { and } \\
2016 \text { and } 0 \text { otherwise }\end{array}$ \\
\hline Crowd_sourcing & $\begin{array}{l}\text { Crowdsourcing as } \\
\text { the source of } \\
\text { knowledge }\end{array}$ & Dummy & $\begin{array}{l}1 \text { if the firm receives new ideas from } \\
\text { crowdsourcing, ideas or inputs from the } \\
\text { general public between } 2014 \text { and } 2016 \text { and } 0 \\
\text { otherwise }\end{array}$ \\
\hline Indus_association & $\begin{array}{l}\text { Industrial } \\
\text { associations as the } \\
\text { source of } \\
\text { knowledge }\end{array}$ & Dummy & $\begin{array}{l}1 \text { if the firm receives new ideas from } \\
\text { professional and industry associations } \\
\text { between } 2014 \text { and } 2016 \text { and } 0 \text { otherwise }\end{array}$ \\
\hline
\end{tabular}

Source: Author work

In the third part, control variables (i.e. industry characteristics, graduate employees and R\&D intensity) are included that might affect the firm's organizational decision to implement open innovation practices. Moreover, following Castellacci (2008) 
classification, we classify the industries in eight innovation trajectories. The detailed information and measurement of the variables and industry classification are presented in Tables 1, 2 and 3.

Table 3

Control variables and industry dummies

\begin{tabular}{|c|c|c|c|}
\hline Variable code & Variable name & Type & Description \\
\hline $\begin{array}{l}\text { Graduate } \\
\text { employees }\end{array}$ & Graduate employees & Centred & $\begin{array}{l}\text { The total number of employees holding a university } \\
\text { degree in survey year (2017), due to continuous } \\
\text { variable, mean is calculated and then centred it. }\end{array}$ \\
\hline National_market & National market & Dummy & $\begin{array}{l}1 \text { if the firm operates in the national market of } \\
\text { Germany and } 0 \text { otherwise }\end{array}$ \\
\hline R\&D Intensity & R\&D Intensity & Continuous & R\&D expenditures as a share of turnover \\
\hline MPG-SB & $\begin{array}{l}\text { Mass production } \\
\text { goods: science-based } \\
\text { manufacturing }\end{array}$ & Dummy & $\begin{array}{l}\text { MPG-SB =1 if firms are classified in mass production } \\
\text { goods: science-based manufacturing (electrical } \\
\text { equipment, media service, chemicals, office } \\
\text { machinery, and computers) and o otherwise }\end{array}$ \\
\hline MPG-SI & $\begin{array}{l}\text { Mass production } \\
\text { goods: scale intensive } \\
\text { manufacturing }\end{array}$ & Dummy & $\begin{array}{l}\text { MPG-SI =1 if firms are classified in mass production } \\
\text { goods: scale intensive manufacturing (mining, plastics, } \\
\text { metals, other non-metallic mineral products, motor } \\
\text { vehicles) and } 0 \text { otherwise }\end{array}$ \\
\hline PGS-M & $\begin{array}{l}\text { Personal goods and } \\
\text { services: } \quad \text { supplier } \\
\text { dominated } \\
\text { manufacturing }\end{array}$ & Dummy & $\begin{array}{l}\text { PGS-M =1 if firms are classified in personal goods and } \\
\text { services: supplier dominated manufacturing (food, } \\
\text { tobacco, textiles, wood, paper, furniture, and toys) } \\
\text { and } 0 \text { otherwise }\end{array}$ \\
\hline AKP-M & $\begin{array}{l}\text { Advanced } \\
\text { knowledge providers: } \\
\text { specialized supplier } \\
\text { manufacturing }\end{array}$ & Dummy & $\begin{array}{l}\text { AKP-M =1 if firms are classified in advanced } \\
\text { knowledge providers: specialized supplier } \\
\text { manufacturing (glass, ceramics, machinery and } \\
\text { equipment, precision and optical instrument) and } 0 \\
\text { otherwise }\end{array}$ \\
\hline AKP-S & $\begin{array}{l}\text { Advanced } \\
\text { knowledge providers: } \\
\text { knowledge-intensive } \\
\text { business services }\end{array}$ & Dummy & $\begin{array}{l}\text { AKP-S }=1 \text { if firms are classified in advanced knowledge } \\
\text { providers: knowledge-intensive business services (IT, } \\
\text { telecommunication or computer and related } \\
\text { activities, technical services and R\&D services, } \\
\text { consulting advertisement or other business activities) } \\
\text { and O otherwise }\end{array}$ \\
\hline PGS-S & $\begin{array}{l}\text { Personal goods and } \\
\text { services: } \quad \text { supplier } \\
\text { dominated services }\end{array}$ & Dummy & $\begin{array}{l}\text { PGS-S }=1 \text { if firms are classified in personal goods and } \\
\text { services: supplier dominated services (automobile, } \\
\text { retail or sales, maintenance and repair of motor } \\
\text { vehicles) and } 0 \text { otherwise }\end{array}$ \\
\hline SIS-N & $\begin{array}{l}\text { Supporting } \\
\text { infrastructure services: } \\
\text { network infrastructure }\end{array}$ & Dummy & $\begin{array}{l}\text { SIS-N = } 1 \text { if firms are classified in supporting infrastructure } \\
\text { services: network infrastructure (banking, insurance } \\
\text { and pension funding, financial intermediation, post, } \\
\text { and telecommunication) and } 0 \text { otherwise }\end{array}$ \\
\hline SIS-P & $\begin{array}{l}\text { Supporting } \\
\text { infrastructure services: } \\
\text { physical infrastructure }\end{array}$ & Dummy & $\begin{array}{l}\text { SIS-P = } 1 \text { if firms are classified in supporting infrastructure } \\
\text { services: physical infrastructure (wholesale, energy, } \\
\text { land, water, supporting and auxiliary transport } \\
\text { activities) and } 0 \text { otherwise }\end{array}$ \\
\hline
\end{tabular}

Note: The industry groups are introduced based on Castellacci, (2008) classification.

Source: Author work

\section{Statistical methods}

The empirical analysis is divided into two steps. The first step provides the descriptive analysis among small and medium-sized firms. Second, to test the hypothesis, a logit regression is used for the main analysis and the robustness checks as well. Since the dependent variable is a binary, which takes the value of 1 if firms introduce the new methods of work responsibility and decision-making at the firm workplace and 0 otherwise, hence, logit estimation seems to be a suitable technique for the analysis (Papke and Wooldridge, 1996). The previous study suggests that if the dependent and independent variables are in a binary or dichotomic nature, a logit regression might be the appropriate technique (see Hair et al., 2010). Also, the logit regression 
technique is used in earlier studies with similar data structures (see Spithoven et al., 2013; Damanpour et al., 2018). To investigate the impact of external knowledge sources on a firm's innovativeness, we use the logistic regression models. For the main analysis, organizational innovation is the dependent variable.

Organizational Inno

$$
\begin{aligned}
& =B_{0}+\beta_{1} \text { (Customer_private) }+\beta_{2} \text { (Customer_public) }+\beta_{3} \text { (Competitors) } \\
& +\beta_{4} \text { (Conferences) }+\beta_{5}(\text { Crowd_sourcing })+\beta_{6}(\text { Indus_association }) \\
& \left.+\beta_{7} \text { (Graduate employees }\right)+\beta_{8}(\text { National_market })+\beta_{9}(\text { R\&D Intensity }) \\
& \left.+\beta_{10} \text { (Industries dummies }\right)
\end{aligned}
$$

For the robustness check, digital innovation supply chain management (Diginnospmana) is the dependent variable.

Diginnospmana

$$
\begin{aligned}
& =B_{0}+\beta_{1} \text { (Customer_private) }+\beta_{2} \text { (Customer_public) }+\beta_{3} \text { (Competitors) } \\
& +\beta_{4} \text { (Conferences) }+\beta_{5}(\text { Crowd_sourcing })+\beta_{6}(\text { Indus_association }) \\
& +\beta_{7}(\text { Graduate employees })+\beta_{8}(\text { National_market })+\beta_{9}(\text { R\&D Intensity }) \\
& \left.+\beta_{10} \text { (Industries dummies }\right)
\end{aligned}
$$

\section{Results}

\begin{tabular}{|c|c|c|c|c|c|c|}
\hline \multirow[b]{2}{*}{ Variables } & \multicolumn{3}{|c|}{$\begin{array}{l}\text { Small firms } \\
\text { (less than } 50 \text { employees) }\end{array}$} & \multicolumn{3}{|c|}{$\begin{array}{l}\text { Medium firms } \\
\text { (50 to } 249 \text { employees) }\end{array}$} \\
\hline & Firms \% & Mean & SD & Firms \% & Mean & SD \\
\hline Organizational innovation & 18.27 & 0.183 & 0.386 & 28.69 & 0.287 & 0.452 \\
\hline Diginnospmana & 4.41 & 0.044 & 0.205 & 9.62 & 0.096 & 0.295 \\
\hline Customer_private & 33.82 & 0.338 & 0.473 & 46.21 & 0.462 & 0.499 \\
\hline Customer_public & 22.28 & 0.223 & 0.416 & 28.38 & 0.284 & 0.451 \\
\hline Ccompetitors & 34.04 & 0.340 & 0.474 & 48.79 & 0.488 & 0.500 \\
\hline Conferences & 32.35 & 0.323 & 0.468 & 47.77 & 0.478 & 0.499 \\
\hline Crowd_sourcing & 11.45 & 0.114 & 0.318 & 14.93 & 0.149 & 0.356 \\
\hline Indus_association & 24.25 & 0.242 & 0.429 & 38.94 & 0.389 & 0.488 \\
\hline Graduate employees & 66.15 & 0.661 & 0.473 & 87.96 & 0.879 & 0.325 \\
\hline National_market & 62.20 & 0.622 & 0.485 & 71.46 & 0.714 & 0.452 \\
\hline R\&D Intensity & - & 0.010 & 0.033 & - & 0.010 & 0.027 \\
\hline MPG-SB & 13.83 & 0.138 & 0.345 & 14.15 & 0.141 & 0.349 \\
\hline MPG-SI & 13.08 & 0.131 & 0.337 & 18.30 & 0.183 & 0.387 \\
\hline AKP-S & 20.31 & 0.203 & 0.402 & 9.93 & 0.099 & 0.299 \\
\hline AKP-M & 4.47 & 0.045 & 0.207 & 6.80 & 0.068 & 0.252 \\
\hline PGS-S & 1.66 & 0.016 & 0.128 & 2.74 & 0.027 & 0.163 \\
\hline SIS-N & 3.25 & 0.032 & 0.177 & 2.81 & 0.028 & 0.165 \\
\hline PGS-M & 17.71 & 0.177 & 0.382 & 20.09 & 0.201 & 0.401 \\
\hline SIS-P & 25.69 & 0.257 & 0.437 & 25.18 & 0.252 & 0.434 \\
\hline Obs. & & 3196 & & & 1279 & \\
\hline
\end{tabular}

Descriptive statistics by firm size

To analyze the effect of various external knowledge sources according to the characteristics of the firm, the sample is separated by firm size (i.e. small and mediumsized firms). Table 4 confirms on average that the use of external knowledge sources is higher in medium-sized firms than in small firms.

Table 4

Descriptive statistics by small and medium-sized firms

Source: Author work

About $29 \%$ of the firms in this dataset introduce organizational innovation in medium firms while $18 \%$ of the firms introduce organizational innovation in the 
workplace for small firms. On the other hand, in medium firms, $9 \%$ of the firms are involved in logistic innovation as digital supply chain management "Diginnospmana" and $4 \%$ of the firms are involved in digital supply chain management in small enterprises. Further, about $66 \%$ in small firms and $88 \%$ in medium firms' employees hold a university degree. Approximately, $71 \%$ of the medium firms and $62 \%$ of the small innovative firms actively seeking business in the national market.

\section{Effect of external knowledge sources on organizational innovation} in small and medium-sized firms

Table 5 presents the results of logit regression for the effect of external knowledge sources on organizational innovation in the workplace by firm size.

Table 5

Results of logit regression for the effect of external knowledge sources on organizational innovation in the workplace by firm size

\begin{tabular}{|c|c|c|c|c|c|c|c|c|}
\hline \multirow[b]{2}{*}{ Variables } & \multicolumn{4}{|c|}{$\begin{array}{l}\text { Small firms } \\
\text { (less than } 50 \text { employees) }\end{array}$} & \multicolumn{4}{|c|}{$\begin{array}{l}\text { Medium firms } \\
\text { ( } 50 \text { to } 249 \text { employees) }\end{array}$} \\
\hline & \multicolumn{2}{|c|}{$\begin{array}{l}\text { Organizational } \\
\text { innovation }\end{array}$} & \multicolumn{2}{|c|}{$\begin{array}{l}\text { dy/dx } \\
\text { (Marg Eff) }\end{array}$} & \multicolumn{2}{|c|}{$\begin{array}{l}\text { Organizational } \\
\text { innovation }\end{array}$} & \multicolumn{2}{|c|}{$\begin{array}{l}d y / d x \\
\text { (Marg Eff) }\end{array}$} \\
\hline \multicolumn{9}{|c|}{ External Knowledge sources } \\
\hline Customer_private & $0.639 * * *$ & $(0.160)$ & $0.086^{* * *}$ & $(0.021)$ & $0.763^{* * *}$ & (0.208) & $0.143^{* * *}$ & (0.038) \\
\hline Customer_public & 0.133 & $(0.132)$ & 0.018 & $(0.018)$ & $-0.324^{*}$ & $(0.169)$ & $-0.061^{*}$ & $(0.032)$ \\
\hline Competitors & $0.566^{* * *}$ & $(0.170)$ & $0.076^{* * *}$ & (0.023) & 0.111 & (0.228) & 0.021 & $(0.043)$ \\
\hline Conferences & $0.280^{*}$ & $(0.165)$ & $0.038^{*}$ & $(0.022)$ & 0.102 & (0.235) & 0.019 & $(0.044)$ \\
\hline Crowd_souring & $0.260^{*}$ & $(0.141)$ & $0.035^{*}$ & (0.019) & 0.260 & $(0.185)$ & 0.049 & $(0.035$ \\
\hline Indus_association & 0.098 & (0.139) & 0.013 & $(0.019)$ & $0.472^{* *}$ & $(0.187)$ & $0.089 * *$ & $(0.035)$ \\
\hline \multicolumn{9}{|c|}{ Control variables and industry dummies } \\
\hline Graduate employees & $0.035^{*}$ & $(0.020)$ & $0.005^{*}$ & (0.003) & 0.019 & $(0.036)$ & 0.004 & $(0.007)$ \\
\hline National_market & $0.310^{* * *}$ & $(0.111)$ & $0.042^{* * *}$ & $(0.015)$ & 0.057 & (0.159) & 0.011 & $(0.030)$ \\
\hline R\&D Intensity & $-3.609 * *$ & (1.432) & $-0.484^{* *}$ & $(0.191)$ & -1.914 & $(2.526)$ & -0.360 & $(0.475)$ \\
\hline MPG-SI & 0.095 & (0.193) & 0.013 & $(0.026)$ & 0.035 & $(0.234)$ & 0.007 & $(0.044)$ \\
\hline AKP-S & 0.309* & (0.165) & $0.041^{*}$ & (0.022) & 0.376 & $(0.266)$ & 0.071 & $(0.050)$ \\
\hline AKP-M & -0.021 & $(0.264)$ & -0.003 & $(0.035)$ & -0.006 & (0.293) & -0.001 & $(0.055)$ \\
\hline PGS-S & -0.301 & (0.402) & -0.040 & $(0.054)$ & -0.208 & $(0.434)$ & -0.039 & $(0.082)$ \\
\hline SIS-N & 0.176 & (0.287) & 0.024 & $(0.038)$ & 0.537 & $(0.404)$ & 0.101 & $(0.076$ \\
\hline PGS-M & 0.056 & $(0.180)$ & 0.008 & $(0.024)$ & -0.131 & $(0.229)$ & -0.025 & $(0.043)$ \\
\hline SIS-P & $0.321 *$ & $(0.170)$ & $0.043^{*}$ & $(0.023)$ & 0.018 & $(0.236)$ & 0.003 & $(0.044)$ \\
\hline Constant & $-2.600 * * *$ & $(0.169)$ & & & $-1.628^{* * *}$ & $(0.233)$ & & \\
\hline LR chi2(16) & \multicolumn{4}{|l|}{305.98} & \multicolumn{4}{|l|}{102.93} \\
\hline Prob > chi2 & \multicolumn{4}{|l|}{0.0000} & \multicolumn{4}{|l|}{0.0000} \\
\hline Pseudo R2 & \multicolumn{4}{|l|}{0.1007} & \multicolumn{4}{|l|}{0.0671} \\
\hline Log likelihood & \multicolumn{4}{|l|}{-1366.728} & \multicolumn{4}{|l|}{-715.1577} \\
\hline Observations & \multicolumn{2}{|l|}{3,196} & \multicolumn{2}{|l|}{3,196} & \multicolumn{2}{|l|}{1,279} & \multicolumn{2}{|l|}{1,279} \\
\hline \multicolumn{9}{|c|}{ Standard errors in parentheses: ${ }^{* * *} p<0.01,{ }^{* *} p<0.05,{ }^{*} p<0.1$} \\
\hline
\end{tabular}

Source: Author work

: - Note in the estimation (in Table 5), organizational innovation is the dependent variable. The reference category in the case of sectoral industry dummies is the mass production goodsscience-based manufacturing (MPG-SB).

In Table 5, the results show that external knowledge gained from the customers in the private sector positively and significantly affects firms' likelihood of doing organizational innovation in SMEs, thus supporting $\mathrm{Hl}$. The marginal effects show that small firms and medium firms ' using private customers as an external knowledge source has an $8.6 \%$ and $14.3 \%$ higher probability of doing organizational innovation, 
respectively. This indicates that the effect of using private sector customers as an external knowledge source on organizational innovation is more pronounced in medium-sized firms than small firms. This finding is in line with the study of Chesbrough (2011) who shows that innovation in services is closely related to the customers.

Similarly, Tether (2005) argues that for organizational orientation in innovation activities, service firms are more likely to collaborate with customers and suppliers. Also, this finding is consistent with the study of Faems et al., (2005) who affirm that customer collaboration positively associates with product innovation. Moreover, external knowledge source from the customer in the public sector has no significant effect in small firms' ability to introduce organisational innovation, while in medium firms, it has a negative significant effect on the introduction of organizational innovation. Hence, $\mathrm{H} 2$ is not supported. The finding is in line with the study of Stuermer et al. (2009), who find that when a firm relies on external sources of innovation; it could bring unexpected costs associated with control and communication. Another possible explanation could be that too much openness towards external information sources of innovation might hamper the search efficiency. In a similar vein, Laursen and Salter (2006) argue that firms that go beyond the optimum level of search strategies and heavily rely on various external knowledge sources of innovation results in a decline in innovation performance.

Furthermore, the small firms using competitors as external knowledge source have a $7.6 \%$ higher probability of doing organizational innovation, this validates $\mathrm{H} 4$. Leiponen (2005) finds the same for Finnish business services firms in case of new service introductions. Similarly, Hipp (2000) states that using competitors as external knowledge source enhances new ideas for innovation in knowledge-intensive business services (KIBS). However, the present study does not find any significant relationship between organizational innovation and competitors as an external knowledge source in the case of medium-sized firms.

In addition, knowledge sourced from external conferences relates significantly positive to organizational innovation in small firms and no effect is observed for the medium-sized firms, thus, $\mathrm{H} 5$ is confirmed for small firms only. Marginal effects show that the small firms sourcing knowledge from external conferences have a $3.8 \%$ higher probability of introducing an organizational innovation than the firms who do not consider conferences as a knowledge source.

Further, knowledge sources from crowdsourcing relate significantly positive with the adoption of organizational innovation in small firms only, hence supporting $\mathrm{H} 3$ for small firms only. This suggests that small firms are more likely to gain from sourced information emanating from crowdsourcing for the introduction of organizational innovation at the workplace.

Additionally, external knowledge sources from the industry association show a positive significant association with the adoption of new methods of organizing work responsibility and decision making in medium-sized firms. Consequently, $\mathrm{H} 6$ is supported for medium-sized firms and not for small firms. This finding indicates that to achieve organizational innovation performance, medium-sized firms could leverage on association with other firms and institution. Love and Mansury (2007) also find that external knowledge sourced from the strategic alliances enhances firms' innovation performance, specifically in terms of the introduction of new services. Further, Pullen et al. (2012) also show that a consistent, closed, and focused network strategy enhance firms' innovation performance.

Concerning control variables, the findings show that employees with higher education have a significant effect on organizational innovation in small firms, in line 
with the study of Mol and Birkinshaw (2009). Furthermore, the small firms targeting the national markets (National_market) have a $4.2 \%$ higher probability of introducing organizational innovation than the small firms not targeting the national market. R\&D intensity shows a negatively significant impact on the introduction of new methods of organizational innovation in small firms. It could be argued that the dearth of resources by small firms could make it challenging for them to invest in R\&D to support organizational innovation. Similarly, Spithoven et al. (2013) analyse the open innovation practices in SMEs and find that R\&D intensity (as a control variable) has no significant effect on the introduction of new product/service development, which is in line with the present study in the case of medium-sized firms.

Lastly, the industries dummies are included as a control since firms' specific characteristics could have a significant effect on innovation. In small firms, the knowledge-intensive business services (AKP-S) have a $4.1 \%$ higher likelihood of the introduction of organizational innovation than small firms active in mass production goods-science-based manufacturing (MPG-SB). Also, in small firms, supporting infrastructure service industries (SIS-P) have a $4.3 \%$ higher likelihood of the introduction of organizational innovation than small firms active in mass production goods-sciencebased manufacturing (MPG-SB). However, there is no significant effect of industry dummies in medium-sized firms.

\section{Robustness check}

To ascertain the stability of the main results in Table 5, a robustness estimation is performed by using a logit model where the dependent variable is digital innovation supply chain management (Diginnospmana). The robustness results illustrate that the findings are robust to using a digital innovation supply chain management "Diginnospmana" as a dependent variable. The coefficients of the estimation variables almost retain their sign and significance in the robustness regression. The results are available upon request from the author.

\section{Discussion}

Over the last years, the innovation concept emerges differently from a technical method to a broader perspective for innovation activities including organizational innovation. Notably, in existing literature, scholars have less focused on the different knowledge sources as a determinant of such type of innovation. Therefore, this study investigates the impact of various external knowledge sources (including customers from the public and private sector, competitors, conferences, crowdsourcing and industry associations) on organizational innovation especially in terms of the adoption of new methods of work organizing responsibility and decision making at firms' workplace.

The findings of this present study lead to the conclusion that source of knowledge from the customers in the private sector, and crowdsourcing have a significant positive effect on organizational innovation in small firms (see Table 5). This indicates that interaction with customers from the private sector and communication with crowdsourcing play an important role in the introduction of organizational innovation in small firms. As the customers and crowdsourcing ideas are relevant to the firms for the adoption of new methods in workplace organization. So, their necessities and desires provide useful knowledge that gives support to the firms to innovate in work organizing tasks as well as in decision making. Further, small firms gaining knowledge from competitors have a higher probability of innovating new organizational methods. 
This suggests that small firm seek information through competitors for the introduction of organizational innovation because competitors also face similar challenges that are linked to cultural and organizational issues. In addition, it also shows that firm interaction and communication with the competitors might support firms to obtain new knowledge that might other firms don't possess for the adoption of new methods of organizational innovation.

Next, conferences as an external information source have a significant positive influence on the performance of organizational innovation at the firm workplace in small firms only. It indicates that small firms generally do not have sufficient resources to conduct their R\&D for the improvement of organizational level. So, small firms take advantage of conferences and trade fairs to obtain new ideas for the development of organizational innovation and improvement in decision-making strategy.

For medium enterprises, the effect of external knowledge source from the private sector has a highly significant impact on the introduction of organizational innovation at the firm workplace. Based on the marginal effect, medium enterprises relatively take more advantage of the use of the information sources through the customer in the private sector than small firms. This suggests that such a knowledge source is useful in enabling them to implement the organizational innovation. Concerning that knowledge obtained through the customer in the public sector has a negative significant effect on the organizational innovation in medium-sized firms; this in effect, indicates that the firms might not require this form of knowledge to support their organizational performance. Another plausible explanation could be the dearth of resources at the disposal of the firm. So, management would have to re-examine such knowledge adoption and integration in their performance strategy.

Furthermore, the medium-sized firms gaining knowledge from industry associations have a higher probability of innovating new organizational methods. The findings suggest that knowledge sourced from the industry associations encourages firms to innovate for new methods of organizing work responsibilities as well as improve decision making skills. Similarly, the business group could provide scientific networks with foreign firms in progressive markets and increase the knowledge sharing process due to their close linkages and knowledge exchange or internal personnel transfer. In addition, a business group comprises a corporation that contains officially autonomous firms that are related to other firms through operating in a common administrative network and financial management (Khanna and Rivkin, 2001).

\section{Conclusion}

Overall results of the present study illustrate that the utilization of external sources of information is a very important aspect that allows firms to adopt organizational innovation at the firm workplace. In general, we can draw a conclusion that through interaction and communication with the external partners (i.e. customers from the private sector, competitors, conferences and crowdsourcing and industry associations) firms can increase their knowledge and reduce the uncertainty about the complex environment in which they operate. Also, the closest association with the informal external knowledge sources supports the organizational innovation at the firm workplace. We can conclude that based on our estimation, external knowledge sources play an essential role in the introduction of organizational innovation in small firms, but not undermining their relevance to medium-sized firms. In effect, small firms are more likely to use various sets of external knowledge sources for the introduction of organizational innovation than medium firms. 


\section{Policy implications for management}

A few practical implications are inferred from this study that is beneficial to managers and the management team as they decide on the suitability of knowledge mix to enhance performance. The decisions of managers and management can mar and at the same time spur the success of a firm. External source of knowledge could stimulate the adoption of new management practices in small and medium enterprise. The present study provides consistent results with the external knowledge source literature on technological innovation, which claims that new ideas and skills for innovation usually come from outside of the working environment of firms.

Concerning the identification of the various sets of external partners available to share their information and knowledge freely may decrease costs that are linked with formal forms of collaboration to enhance organizational innovation in the workplace. The closest association with the informal external knowledge sources may support the internal and external organizational innovation at the firm level. The results of our findings suggest that managers should establish a better connection with the customers, competitors, industry association, crowdsourcing and trade fair exhibitions to benefit from the mix of external information for the potential development of organizational innovation.

\section{Limitation and future research}

This study has some limitations that further research with available dataset could address. This study uses a cross-sectional dataset and reveals external sources of knowledge as an essential determinant of organizational innovation performance in small and medium-sized firms, respectively. As a result, this study could not estimate the long-term impact of external knowledge sources on organizational innovation. However, it does not becloud the relevant findings that are quintessential to the internal performance of firms in the way things are organized. As it is difficult to observe the causality problems in a cross-sectional dataset, future research might consider the causality issues when the appropriate data is available. Further, future research might provide a cross-country comparison with a longer period. Finally, for future research, the following might be considered; how various external knowledge sources support the enterprise strategies or goals (e.g. reducing in house costs of operation, reducing costs of purchased material or services and increase the quality of existing goods and services).

\section{References}

1. Abdul Basit, S., Kuhn, T., Ahmed, M. (2018), "The Effect of Government Subsidy on NonTechnological Innovation and Firm Performance in the Service Sector: Evidence from Germany", Business Systems Research, Vol. 9 No. 1, pp. 118-137.

2. Al-Laham, A., Amburgey, T. L., Baden-Fuller, C. (2010), "Who is my partner and how do we dance? Technological collaboration and patenting speed in US biotechnology", British Journal of Management, Vol. 21 No. 3, pp. 789-807.

3. Anzola-Román, P., Bayona-Sáez, C., García-Marco, T. (2018), "Organizational innovation, internal R\&D and externally sourced innovation practices: Effects on technological innovation outcomes", Journal of Business Research, Vol. 91, pp. 233-247.

4. Bach, M. P., Lojpur, A., Peković, S., Stanovčić, T. (2015), "The influence of different information sources on innovation performance: Evidence from France. The Netherlands and Croatia",. South East European Journal of Economics and Business, Vol. 10 No. 2, pp. 89-101. 
5. Birkinshaw, J., Hamel, G., Mol, M. J. (2008), "Management innovation", Academy of management Review, Vol. 33 No.4, pp. 825-845.

6. Bogers, M., Zobel, A.-K., Afuah, A., Almirall, E., Brunswicker, S., Dahlander, L., Frederiksen, L., Gawer, A., Gruber, M., Haefliger, S. (2017), "The open innovation research landscape: established perspectives and emerging themes across different levels of analysis", Industry and Innovation, Vol. 24 No.1, pp. 8-40.

7. Brettel, M., Cleven, N. J. (2011), "Innovation culture, collaboration with external partners and NPD performance", Creativity and Innovation Management, Vol.20 No.4, pp. 253272.

8. Brunswicker, S., Vanhaverbeke, W. (2015), "Open innovation in small and medium-sized enterprises (SMEs): External knowledge sourcing strategies and internal organizational facilitators", Journal of Small Business Management, Vol. 53 No.4, pp. 1241-1263.

9. Castellacci, F. (2008), "Technological paradigms, regimes and trajectories: Manufacturing and service industries in a new taxonomy of sectoral patterns of innovation", Research Policy, Vol. 37 No.6-7, pp. 978-994.

10. Chang, S. J., Chung, C. N., Mahmood, I. P. (2006), "When and how does business group affiliation promote firm innovation? A tale of two emerging economies", Organization Science, Vol.17 No. 5, pp. 637-656.

11. Chang, W., Taylor, S. A. (2016), "The effectiveness of customer participation in new product development: A meta-analysis", Journal of Marketing, Vol. 80 No.1, pp. 47-64.

12. Chen, Q., Wang, C. H., Huang, S. Z. (2019), "Effects of organizational innovation and technological innovation capabilities on firm performance: evidence from firms in China's Pearl River Delta", Asia Pacific Business Review, Vol. 26 No.1, pp. 1-25.

13. Chesbrough, H. (2003), "Open Innovation: The New Imperative for Creating and Profiting From Technology", Boston, MA, Harvard Business School Press.

14. Chesbrough, H. (2011), "Open services innovation: Rethinking your business to grow and compete in a new era", San Francisco, CA, Jossey Bass A Wiley Imprint.

15. Chesbrough, H., Vanhaverbeke, W., West, J., Eds., (2006), "Open innovation: Researching a new paradigm", New York, Oxford University Press.

16. Chesbrough, H., Vanhaverbeke, W., West, J., (2014), "New frontiers in open innovation", Oxford, Oxford University Press.

17. Choi, S. B., Lee, S. H., Williams, C. (2011), "Ownership and firm innovation in a transition economy: Evidence from China", Research Policy, Vol. 40No.3, pp. 441-452.

18. Cohen, W. M., Levinthal, D. A. (1990), "Absorptive capacity: A new perspective on learning and innovation", Administrative science quarterly, Vol. 35 No.1, pp. 128-152.

19. Criscuolo, P., Laursen, K., Reichstein, T., Salter, A. (2018), "Winning combinations: search strategies and innovativeness in the UK", Industry and Innovation, Vol. 25No.2, pp. 115143.

20. Damanpour, F. (2014), "Footnotes to research on management innovation",. Organization Studies, Vol. 35 No. 9, pp. 1265-1285.

21. Damanpour, F., Sanchez-Henriquez, F., Chiu, H. H. (2018), "Internal and external sources and the adoption of innovations in organizations", British Journal of Management, Vol. 29 No.4, pp. 712-730.

22. Dotzel, K. R., Faggian, A. (2019), "The impact of external knowledge sourcing on innovation outcomes in rural and urban businesses in the US", Growth and Change, Vol. 50 No.2, pp. 515-547.

23. Faems, D., Van Looy, B., Debackere, K. (2005), "Interorganizational collaboration and innovation: Toward a portfolio approach", Journal of product innovation management, Vol. 22 No.3, pp. 238-250.

24. Ferraris, A., Santoro, G., Dezi, L. (2017), "How MNC's subsidiaries may improve their innovative performance? The role of external sources and knowledge management capabilities", Journal of Knowledge Management, Vol. 21 No. 3, pp. 540-552.

25. Fitjar, R. D., Rodríguez-Pose, A. (2013), "Firm collaboration and modes of innovation in Norway", Research Policy, Vol. 42 No.1, pp. 128-138. 
26. Gassmann, O., Enkel, E. (2004), "Towards a theory of open innovation: three core process archetypes", In Proceedings of the R\&D Management Conference, Lisbon, July 6-9, RADMA, Portugal, pp.1-18.

27. Gassmann, O., Enkel, E., Chesbrough, H. (2010), "The future of open innovation", R\&D Management, Vol.40 No.3, pp. 213-221.

28. Gellynck, X., Vermeire, B. (2009), "The contribution of regional networks to innovation and challenges for regional policy", International Journal of Urban and Regional Research, Vol. 33 No.3, pp. 719-737.

29. Gnyawali, D.R., Park, B.J., (2011), "Co-opetition between giants: collaboration with competitors for technological innovation", Research Policy. Vol. 40 No.5, pp. 650-663.

30. Gómez, J., Salazar, I., Vargas, P. (2016), "Sources of information as determinants of product and process innovation", PLoS One, Vol. 11 No.4, e0152743.

31. Greenan, N., Mairesse, J. (2003), "How do new organizational practices shape production jobs", working paper No. 28, Centre d'études de l'emploi et du travail, France, September 2003.

32. Gulerwe, I., Guillén, M. F., Macpherson, J. M. (2002), "Global competition, institutions, and the diffusion of organizational practices: The international spread of ISO 9000 quality certificates", Administrative science quarterly, Vol. 47 No. 2, pp. 207-232.

33. Hair, J., Black, W. C., Babin, B. J., Anderson, R. E. (2010), "Multivariate data analysis", (7th ed.), Pearson Prentice Hall, available at: http://library.wur.nl/WebQuery/clc/1809603 (12 November 2019).

34. Hall, R. (1992), "The strategic analysis of intangible resources", Strategic management journal, Vol. 13 No.2, pp. 135-144.

35. Hervas-Oliver, J. L., Sempere-Ripoll, F., Boronat-Moll, C., Rojas, R. (2015), "Technological innovation without R\&D: unfolding the extra gains of management innovations on technological performance", Technology Analysis \& Strategic Management, Vol. 27 No.1, pp. 19-38.

36. Hinteregger, C., Durst, S., Temel, S., Yesilay, R. B. (2019), "The impact of openness on innovation in SMEs", International Journal of Innovation Management, Vol. 23 No.01, 1950003.

37. Hipp, C. (2000), "Information flows and knowledge creation in knowledge-intensive business services: scheme for a conceptualization", in Metcalfe J.S., Miles I. (Ed.), Innovation Systems in the Service Economy, Boston, MA, Springer, pp. 149-167.

38. Hippel, E.V. (1988), "The Sources of Innovation", New York, Oxford University Press.

39. Hossain, M. (2013), "Open innovation: so far and a way forward", World Journal of Science, Technology and Sustainable Development, Vol.10 No.1, pp. 30-41.

40. Iglesias-Sánchez, P. P., Correia, M. B., Jambrino-Maldonado, C. (2019), "Challenges of Open Innovation in the Tourism Sector", Tourism Planning \& Development, Vol.16 No.1, pp. 22-42.

41. Kang, K. H., Kang, J. (2009), "How do firms source external knowledge for innovation? Analysing the effects of different knowledge sourcing methods", International Journal of Innovation Management, Vol.13 No.01, pp. 1-17.

42. Keupp, M. M., Palmié, M., Gassmann, O. (2012), "The strategic management of innovation: A systematic review and paths for future research", International Journal of Management Reviews, Vol.14 No.4, pp. 367-390.

43. Khanna, T., Rivkin, J. W. (2001), "Estimating the performance effects of business groups in emerging markets", Strategic Management Journal, Vol. 22 No.1, pp. 45-74.

44. Knoben, J., Oerlemans, L. A. G. (2010), "The importance of external knowledge sources for the newness of innovations of South African firms", International Journal of Innovation and Regional Development, Vol. 2 No.3, pp. 165-181.

45. Köhler, C., Sofka, W., Grimpe, C. (2012), "Selective search, sectoral patterns, and the impact on product innovation performance", Research Policy, Vol.41 No.8, pp. 13441356. 
46. Laursen, K., Salter, A. (2006), "Open for innovation: the role of openness in explaining innovation performance among UK manufacturing firms", Strategic management journal, Vol.27 No.2, pp. 131-150.

47. Lefebvre, V. M., De Steur, H., Gellynck, X. (2015), "External sources for innovation in food SMEs", British Food Journal, Vol. 117 No.1, pp. 412-430.

48. Leiponen, A. (2005), "Organization of knowledge and innovation: the case of Finnish business services", Industry \& Innovation, Vol.12 No.2, pp. 185-203.

49. Leiponen, A., Helfat, C. E. (2011), "Location, decentralization, and knowledge sources for innovation", Organization Science, Vol. 22 No.3, pp. 641-658.

50. Lhuillery, S.,Pfister, E. (2009), "R\&D cooperation and failures in innovation projects: Empirical evidence from French CIS data", Research policy, Vol.38 No.1, pp. 45-57.

51. Love, J. H., Mansury, M. A. (2007), "External linkages, R\&D and innovation performance in US business services", Industry and Innovation, Vol.1 4 No.5, pp. 477-496.

52. Mol, M. J.,Birkinshaw, J. (2009), "The sources of management innovation: When firms introduce new management practices", Journal of business research, Vol. 62 No.12, pp. 1269-1280.

53. Mol, M. J.,Birkinshaw, J. (2014), "The role of external involvement in the creation of management innovations", Organization Studies, Vol. 35 No.9, pp. 1287-1312.

54. Mowery, D. C., Oxley, J. E., Silverman, B. S. (1996), "Strategic alliances and interfirm knowledge transfer", Strategic Management Journal, Vol.17 No. S2 - Winter Special Issue, pp. 77-91.

55. Muller, P., Caliandro, C., Peycheva, V., Gagliardi, D., Marzocchi, C., Ramlogan, R., Cox, D. (2015), "Annual report on European SMEs", European Commission, available at: https://op.europa.eu/en/publication-detail/-/publication/7c9fbfe0-e044-1 1 e5-8fea01 aa75ed7l al/language-en/format-PDF/source-208087183, (15 November 2019).

56. OECD. (2005), "The measurement of scientific and technological activities", in Oslo Manual, Guidelines for collecting and interpreting innovation data (3rd ed.), OECD EUROSTAT, available at: https://ec.europa.eu/eurostat/documents/3859598/5889925/OSLO-EN.PDF/60a5a2f5577a-4091-9e09-9fa9e741 dcf1 ?version=1.0, (10 November 2019).

57. Papke, L. E., Wooldridge, J. M. (1996), "Econometric methods for fractional response variables with an application to 401 (k) plan participation rates", Journal of applied econometrics, Vol. 11 No.6, pp. 619-632.

58. Pippel, G. (2014), "R\&D cooperation for non-technological innovations", Economics of Innovation and New Technology, Vol. 23 No.7, pp. 611-630.

59. Pullen, A. J., de Weerd-Nederhof, P. C., Groen, A. J., Fisscher, O. A. (2012), "Open innovation in practice: goal complementarity and closed NPD networks to explain differences in innovation performance for SMEs in the medical devices sector", Journal of product innovation management, Vol. 29 No.6, pp. 917-934.

60. Reed, R., DeFillippi, R. J. (1990), "Causal ambiguity, barriers to imitation, and sustainable competitive advantage", Academy of management review, Vol.15 No.1, pp. 88-102.

61. Santoro, G., Ferraris, A., Giacosa, E., Giovando, G. (2018a), "How SMEs Engage in Open Innovation: a Survey", Journal of Knowledge Economy, Vol.9 No.2, SI, pp. 561-574.

62. Santoro, G., Vrontis, D., Thrassou, A., Dezi, L. (2018b), "The internet of things: building a knowledge management system for open innovation and knowledge management capacity", Technological Forecasting and Social Change, Vol.136, pp. 347-354.

63. Schumpeter, J. A. (1934), "The theory of economic development", Cambridge, MA, Harvard University Press,

64. Sofka, W., Grimpe, C. (2010), "Specialized search and innovation performanceevidence across Europe", R\&D Management, Vol.40 No.3, pp. 310-323.

65. Spithoven, A., Vanhaverbeke, W. Roijakkers, N. (2013), "Open innovation practices in SMEs and large enterprises", Small Business Economics, Vol.41 No.3, pp. 537-562.

66. Stuermer, M., Spaeth, S., Von Krogh, G. (2009), "Extending private-collective innovation: a case study", R\&D Management, Vol.39 No.2, pp. 170-191. 
67. Teece, D. J. (1986), "Profiting from technological innovation: Implications for integration, collaboration, licensing and public policy", Research policy, Vol.15 No.6, pp. 285-305.

68. Tether, B. S. (2002), "Who co-operates for innovation, and why: an empirical analysis", Research policy, Vol. 31No.6, pp. 947-967.

69. Tether, B. S. (2005), "Do services innovate (differently)? Insights from the European innobarometer survey", Industry \& Innovation, Vol.12 No.2, pp. 153-184.

70. Tether, B. S., Tajar, A. (2008 a), "Beyond industry-university links: Sourcing knowledge for innovation from consultants, private research organisations and the public sciencebase", Research Policy, Vol.37 No.6-7, pp. 1079-1095.

71. Tether, B. S., Tajar, A. (2008b), "The organisational-cooperation mode of innovation and its prominence amongst European service firms", Research policy, Vol. 37 No.4, pp. $720-$ 739.

72. Tidd, J., Bessant, J., Pavitt, K. (2005), "Managing Innovation: Integrating Technological, Market, and Organization Change", 3rd ed., Chichester, UK, John Wiley and Sons.

73. Tsai, K. H. (2009), "Collaborative networks and product innovation performance: Toward a contingency perspective", Research Policy, Vol.38 No.5, pp. 765-778.

74. Tsoukas, H. (1996), "The firm as a distributed knowledge system: A constructionist approach", Strategic management journal, Vol.17 No. S2, pp. 11-25.

75. Turulja, L., Bajgorić, N. (2018), "Knowing Means Existing: Organizational Learning Dimensions and Knowledge Management Capability", Business Systems Research, Vol.9 No.1, pp. 1-18.

76. Van de Vrande, V., De Jong, J. P., Vanhaverbeke, W., De Rochemont, M. (2009), "Open innovation in SMEs: Trends, motives and management challenges", Technovation, Vol. 29 No.6-7, pp. 423-437.

77. Volberda, H. W., Van Den Bosch, F. A., Mihalache, O. R. (2014), "Advancing management innovation: Synthesizing processes, levels of analysis, and change agents" Organization Studies, Vol.35 No.9, pp. 1245-1264.

78. Wang, $X ., X U, M .(2018)$, "Examining the linkage among open innovation, customer knowledge management and radical innovation: The multiple mediating effects of organizational learning ability", Baltic Journal of Management, Vol.13 No.3, pp. 368-389.

79. West, J., Bogers, M. (2014), "Leveraging external sources of innovation: a review of research on open innovation", Journal of Product Innovation Management, Vol. 31 No.4, pp. 814-831.

80. Wynarczyk, P. (2013), "Open innovation in SMEs: a dynamic approach to modern entrepreneurship in the twenty-first century", Journal of Small Business and Enterprise Development, Vol. 20 No.2, pp. 258-278.

81. Yiu, D. W., Bruton, G. D., LU, Y. (2005), "Understanding business group performance in an emerging economy: Acquiring resources and capabilities in order to prosper", Journal of Management Studies, Vol. 42 No.1, pp. 183-206.

82. Zouaghika, F., Sánchez, M., Martínez, M. G. (2018), "Did the global financial crisis impact firms' innovation performance? The role of internal and external knowledge capabilities in high- and low-tech industries", Technological Forecasting and Social Change, Vol. 132, pp. 92-104. 


\section{About the author}

Shoaib Abdul Basit, M.Sc. is a PhD student at the Faculty of Economics and Business Administration, TU Chemnitz, Germany. He participated in the 17th International Joseph A. Schumpeter Society (ISS) conference on "Innovation, Catch-up, and sustainable development in Seoul, South Korea. He has published papers in good journals such as the European Journal of Innovation Management and Journal of Innovation \& Knowledge. His main research interests lie in the economics of innovation, knowledge exploitation, firm strategy, innovation and market environment. The author can be contacted at shoaibkherani_iivi@yahoo.com. 